\title{
LEI0258 microsatellite variability and its relationship to $B-F$ haplotypes in Brazilian (blue-egg Caipira) chickens
}

\author{
Carlos André da Veiga Lima-Rosa ${ }^{1}$, Cláudio Wageck Canal ${ }^{2}$, Paulo Roberto Vargas Fallavena ${ }^{1}$, \\ Loreta Brandão de Freitas ${ }^{1}$ and Francisco Mauro Salzano ${ }^{1}$ \\ ${ }^{1}$ Universidade Federal do Rio Grande do Sul, Instituto de Biociências, Departamento de Genética, \\ Porto Alegre, RS, Brazil. \\ ${ }^{2}$ Universidade Federal do Rio Grande do Sul, Faculdade de Veterinária, \\ Centro de Diagnóstico e Pesquisa em Patologia Aviária, Porto Alegre, RS, Brazil.
}

\begin{abstract}
A total of 149 chickens from two different sources (one non-commercial, the other commercial) was tested for variability of the LEI0258 microsatellite. Fifty- three genotypes, explainable by 15 alleles, were found. There are clear allele and heterozygosity differences between the two samples. One of them was simultaneously studied for the MHC $B-F$ haplotypes. Strong genetic disequilibrium was observed between the variants of the two systems, therefore providing a cheap alternative for MHC genotyping.
\end{abstract}

Key words: microsatellite, LEI0258, B-F haplotypes, Brazilian chickens.

Received: April 13, 2004; Accepted: February 15, 2005.

Microsatellites (also called short tandem repeats or STRs) are moderately repetitive DNA sequences with small core sizes (di-, tri- or tetranucleotides mainly) that have been widely used to map genes, characterize inbred lineages, associate normal with pathological conditions, and uncover interpopulation differences. Examples in chickens are the studies of Kaiser et al. (2000), Wardecka et al. (2002), and Yunis et al. (2002), in which they have been used to characterize broiler populations, and were associated with egg production, quality traits, and antibody responses. McConnell et al. (1999) described one such tetranucleotide repeat system (LEI0258), located in chicken's microchromosome 16. Molecular markers in this chromosome are of special interest, since the major histocompatibility B complex also occurs there (Wain et al., 1998). More specifically, this microsatellite is placed near the $B-F / B-L$ region. Genes in this DNA segment codify molecules which are responsible for the presentation of endogenous (B-F) and exogenous (B-L) antigens to the effector cells, therefore starting the whole chain of the immune response (Abbas et al., 2000). It was shown that alleles or haplotypes in this region can influence the resistance or susceptibility to many avian diseases. For in-

Send correspondence to Francisco Mauro Salzano. Universidade Federal do Rio Grande do Sul, Departamento de Genética, Caixa Postal 15053, 91501-970 Porto Alegre, RS, Brazil. E-mail: francisco.salzano@ufrgs.br. stance, haplotype B21 confer resistance, B2, B6, and B14 moderate resistance and B19 susceptibility to Marek Disease (Kaufman, 2000).

We recently investigated the $B$ - $F$ region of a Brazilian (blue-egg Caipira) breed. Twenty-three sequences were obtained, of which at least 10 were novel, confirming these animals as potential sources for genes resistant to diseases and adverse climate, temperature, and food conditions. Fourteen different haplotypes were identified (Lima-Rosa et al., 2004). It is important to verify whether the LEI0258 variants are associated with these haplotypes, since they could provide markers that are detectable with an easier (and cheaper) laboratory method than sequencing. This was the objective of the present investigation. In addition, we wanted to verify whether different Caipira populations would present significant genetic heterogeneity.

Two populations were studied. The first was represented by 100 blue-egg Caipira chickens. The word Caipira derives from the Tupi-Guarani and means "habitant of the field." It is applied to domestic chickens in general, bred freely in the courtyards of rural or urban houses. An interesting characteristic of some of these chickens is that they may oviposite blue eggs. This trait appeared first in Chilean Araucana chickens, that around 1880 expanded to Brazil and crossed with Caipira, originating then the blue-egg Caipira chickens (Albino et al., 2001; M.N. Sales, personal communication). Blue eggs were collected in farms from Dois Lageados county, state of Rio Grande do Sul, Brazil. 
They were then placed in an incubator machine (Petersime Industrial SA, Urusanga, SC, Brazil) until hatching.

The other population was constituted by 49 animals from the Paraíso Pedrês commercial line, purchased from the Aves do Paraíso farm, located at km 10 of the Romildo Prado highway, in Itatiba, state of São Paulo, Brazil. This broiler breed was selected by crossing Caipira chickens with selected standard races, to obtain commercially valuable and homogeneous lineages (Ramos, 1995). Eleven of them were then intercrossed, leading to this Paraíso Pedrês breed. Peripheral blood was obtained from these and the other chicks using $0.5 \%$ EDTA as anticoagulant.

Genomic DNA was extracted from the birds' erythrocytes using Sambrook et al. (1989) standard method. Amplification by the polymerase chain reaction (PCR) was performed as described by McConnell et al. (1999), with some adjustments, from total DNA. The primers used were those described by these authors: forward (5'-CACGCAGCAGAACTTGGTAAGG-3') and reverse (5'-AGCTGTGCTCAGTCCTCAGTGC-3'). The mixtures for the $\mathrm{PCR}$ reactions, and reagent concentrations, were as follows: $50 \mathrm{ng}$ of DNA, $2.5 \mu \mathrm{L}$ of $10 \mathrm{x}$ buffer (100 mM tris- $\mathrm{HCl}, \mathrm{pH} 8.3,500 \mathrm{mM} \mathrm{KCl}, 15 \mathrm{mM} \mathrm{Mg} \mathrm{Cl}_{2}$ ), $2.5 \mu \mathrm{L}$ of PCRx Enhancer System buffer (Invitrogen Life Technologies), $2 \mu \mathrm{L}$ of dNTP mix (1.25 mM of dATP, $\mathrm{dCTP}$, dGTP, and dTTP), one $\mu \mathrm{M}$ of each primer, 0.25 units of Platinum Taq DNA polymerase (Invitrogen Life Technologies) and distilled water to obtain a final volume of $25 \mu \mathrm{L}$. The amplification conditions consisted of a 1-minute initial denaturation at $96{ }^{\circ} \mathrm{C}$, followed by 351 -minute denaturation cycles at $96{ }^{\circ} \mathrm{C}, 30 \mathrm{~s}$ annealing at $54{ }^{\circ} \mathrm{C}, 30 \mathrm{~s}$ extension at $72^{\circ} \mathrm{C}$, and 3 -minutes of final extension at $72{ }^{\circ} \mathrm{C}$. The PCR products were analyzed by vertical electrophoresis in $7 \%$ non-denaturing polyacrilamide gel (Lahiri et al., 1997).

The $B-F$ haplotype variability in the blue-egg Caipira sample had been previously evaluated through sequencing and cloning techniques described in Lima-Rosa et al. (2004). Briefly, the primers were those indicated by Li et al. (1997), the PCR conditions those described by Li et al. (1997) and Ennis et al. (1990), and the sequences were obtained using a MegaBACE 1000 machine. As for the cloning studies, they were performed using the Topo TA Cloning Kit for Sequencing (Invitrogen Life Technologies).

The alleles were identified by their sizes, and allele frequencies were determined by gene counting. Fit to the Hardy-Weinberg equilibrium was determined by the Markov chain method (Guo and Thompson, 1992) using version 2000 of the Arlequin program (Schneider et al., 2000). The interpopulation comparison of the allele frequencies was performed by the chi-square test (Roff and Bentzen, 1989), while the LEI0258/B- $F$ linkage disequilibrium was also determined by the Arlequin program, with D' (the degree of departure from equilibrium) manually calculated as described by Lewontin (1988).

Fifty-three genotypes were found, 19 only in the blue-egg Caipira and 25 only in Paraíso Pedrês, nine, therefore, occurring in the two populations. Genotype 217/217 was the most frequent $(30 \%)$ in the blue-egg Caipira chickens, followed by $217 / 325$ (9\%). In the Paraíso Pedrês sample almost all genotypes varied from 2 to $4 \%$, the exception being $205 / 205$, with a frequency of $8 \%$ (detailed information available on request). Allele frequency information is given in Table 1. A total of 15 alleles were observed in the 149 chickens tested, their sizes varying between 205 and $457 \mathrm{bp}$. Nine alleles were present in the two samples. Alleles 313,337 , and 421 were only found among the blue-egg Caipira chickens, while 373, 385, and 457 occurred exclusively in the Paraíso Pedrês sample. There are clear allele differences between the two populations $\left(\chi^{2}=111.4 ; \mathrm{p}<0.0001\right)$. The three most frequent alleles in the blue-egg Caipira sample were 217 (42\%), 325 (16\%), and $265(15 \%)$, while for Paraíso Pedrês they were 265 $(16 \%), 397(15 \%)$, and 205 (14\%). The observed heterozygosity was $50 \%$ in blue-egg Caipira and $75 \%$ in Paraíso Pedrês chickens. Good genotype frequency fit to the Hardy-Weinberg predictions was obtained in the Paraíso Pedrês (p:0.207) but not in the blue-egg Caipira $(\mathrm{p}<0.001)$ samples.

The number of alleles observed in our material is high (15); the study of other microsatellites by other authors in non-commercial chickens detected, at most, 11 alleles per locus (Takahashi et al., 1998; Zhou and Lamont, 1999; Wimmers et al., 1999, 2000; Marle-Köster and Nel, 2000).

Table 1 - LEI0258 allele frequencies in two samples of Brazilian chickens.

\begin{tabular}{lcc}
\hline Allele $^{1}$ & Blue-egg Caipira (\%) & Paraíso Pedrês (\%) \\
\hline 205 & 8.0 & 14.3 \\
217 & 42.0 & 10.2 \\
229 & 2.0 & 3.1 \\
265 & 15.0 & 16.3 \\
277 & 8.0 & 7.1 \\
301 & 3.5 & 2.0 \\
313 & 0.5 & - \\
325 & 16.0 & 4.1 \\
337 & 2.5 & - \\
373 & - & 8.2 \\
385 & - & 5.1 \\
397 & 0.5 & 15.3 \\
409 & 1.5 & 4.1 \\
421 & 0.5 & - \\
457 & - & 10.2 \\
Total & 100 & \\
\hline
\end{tabular}

${ }^{1}$ Size in number of base pairs. 
This could be due to the fact that LEI0258 is located in a region where genes of the major histocompatibility B complex also occur, which could be under the influence of diversifying selection. This type of selection generates diversity not only in the alleles under its influence, but also in adjoining regions (the so-called hitchhiking effect). Regardless of its causes, the LEI0258 variability could be quite useful in the investigation of several academic and applied problems.

Our samples derived from two distinct populations, one which was subjected to artificial selection for meat production and quality, while the other was from animals freely raised in farms, without this type of intentional breeding. The number of alleles detected in each (12), however, was the same. Allele distribution and degree of heterozygosity, on the other hand, were different. This is not surprising, since they originated from widely separated (about one thousand kilometers) populations. In the absence of detailed information about their founders and of experimental data, we can only speculate about the factors which may explain these results. Founder or sampling effects, sexual selection (unequal contribution of genetically different males in the two groups), or even some adaptive advantage of given alleles may have influenced these distributions.

Information about the association between the LEI0258 alleles and $B-F$ haplotypes in the blue-egg Caipira chickens is provided in Table 2. Eight alleles (205, 229, $301,313,337,397,409,421)$ showed association with just one, two $(277,325)$ with two, and other two $(217,265)$ with three $B-F$ haplotypes. $B F^{*} C C 14$ was the only haplotype associated with two LEI0258 alleles (313 and 337). Linkage disequilibrium was quite high $\left(\chi^{2}=637.3 ; \mathrm{p}<0.0001\right)$.

The strong association between LEI0258 alleles and $B-F$ haplotypes has important theoretical and practical applications. First, the microsatellites may provide indirect information about the population distribution of $B-F$ markers. But perhaps of higher value is the fact that in $67 \%$ of the cases there was a direct correspondence between a given LEI0258 allele and a specific $B-F$ haplotype, providing an easier method for determination of the latter ( $B-F$ typing generally requires sequencing techniques). Even in the case where more than one $B-F$ haplotype is associated with a LEI0258 allele, allele specific (PCR-SSP; Polymerase Chain Reaction with Sequence Specific Primers) selective typing can be performed, thus considerably reducing the cost of $B-F$ genotyping. Of course, our sample was limited in size (100 animals), and different associations can be found in other breeds. But the results are valuable in that they draw attention to a source of variation not previously widely explored that can be used in a variety of ways.

We would like to thank Marilu Fiegenbaum and Silvana de Almeida for statistical help. This research was supported by Programa de Apoio a Núcleos de Excelência (PRONEX), Conselho Nacional de Desenvolvimento
Table 2 - Association between the LEI0258 alleles and $B-F$ haplotypes in blue-egg Caipira chickens.

\begin{tabular}{|c|c|c|c|}
\hline \multirow[t]{2}{*}{ LEI0258 allele } & \multirow[t]{2}{*}{$B-F$ haplotype ${ }^{1}$} & \multicolumn{2}{|c|}{ Frequency } \\
\hline & & $\mathrm{N}$ & $\%$ \\
\hline 205 & $B F^{*} C C 1$ & 16 & 8.0 \\
\hline \multirow[t]{3}{*}{217} & $B F^{*} C C 3$ & 21 & 10.5 \\
\hline & $B F^{*} C C 4$ & 43 & 21.5 \\
\hline & $B F^{*} C C 15$ & 19 & 9.5 \\
\hline 229 & $B F^{*} C C 5$ & 4 & 2.0 \\
\hline \multirow[t]{3}{*}{265} & $B F^{*} C C 6$ & 2 & 1.0 \\
\hline & $B F^{*} C C 7$ & 17 & 8.5 \\
\hline & $B F^{*} C C 8$ & 11 & 5.5 \\
\hline \multirow[t]{2}{*}{277} & $B F^{*} C C 9$ & 4 & 2.0 \\
\hline & $B F^{*} C C 16$ & 12 & 6.0 \\
\hline 301 & $B F^{*} C C 10$ & 7 & 3.5 \\
\hline 313 & $B F^{*} C C 14$ & 1 & 0.5 \\
\hline \multirow[t]{2}{*}{325} & $B F^{*} C C 13$ & 20 & 10.0 \\
\hline & $B F^{*} C C 17$ & 13 & 6.5 \\
\hline 337 & $B F^{*} C C 14$ & 5 & 2.5 \\
\hline 397 & $B F^{*} C C 2$ & 1 & 0.5 \\
\hline 409 & $B F^{*} C C 11$ & 3 & 1.5 \\
\hline 421 & $B F^{*} C C 12$ & 1 & 0.5 \\
\hline Total & & 200 & 100 \\
\hline
\end{tabular}

${ }^{1} B-F^{*} C C 15, B-F^{*} C C 16$, and $B-F^{*} C C 17$ had not been described by Lima-Rosa et al. (2004), but were identified with essentially the same methods described by these authors.

$\mathrm{N}$ : number of chromosomes examined.

Científico e Tecnológico (CNPq), Financiadora de Estudos e Projetos (FINEP), Fundação de Amparo à Pesquisa do Estado do Rio Grande do Sul (FAPERGS), and Pró-Reitoria de Pesquisa da Universidade Federal do Rio Grande do Sul (PROPESQ/UFRGS).

\section{References}

Abbas AK, Lichtman AH and Pober JS (2000) Cellular and Molecular Immunology. $4^{\text {th }}$ edition. W.B. Saunders, Philadelphia, $553 \mathrm{pp}$.

Albino LFT, Vargas Jr JG and Silva JHV (2001) Criação de Frango e Galinha Caipira - Avicultura Alternativa. Aprenda Fácil Editora, Viçosa, MG, 120 pp.

Ennis PD, Zemmour J, Salter RD and Parham P (1990) Rapid cloning of HLA-A,B cDNA by using the polymerase chain reaction: Frequency and nature of errors produced in amplification. Proc Nat Acad Sci USA 87:2833-2837.

Guo SW and Thompson EA (1992) Performing the exact test of Hardy-Weinberg proportions for multiple alleles. Biometrics 48:361-372.

Kaiser MG, Yonash N, Cahaner A and Lamont SJ (2000) Microsatellite polymorphism between and within broiler populations. Poult Sci 79:626-628. 
Kaufman J (2000) The simple chicken major histocompatibility complex: Life and death in the face of pathogens and vaccines. Phil Trans R Soc Lond B 355:1077-1084.

Lahiri DK, Zhang A and Nurnberger JI (1997) High-resolution detection of PCR products from microsatellite markers using a nonradioisotopic technique. Biochem Mol Med 60:70-75.

Lewontin RC (1988) On measures of gametic disequilibrium. Genetics 120:849-852.

Li L, Johnson WL and Ewald SJ (1997) Molecular characterization of major histocompatibility complex (B) haplotypes in broiler chickens. Anim Genet 28:258-267.

Lima-Rosa CAV, Canal CW, Streck AF, Freitas LB, Cañedo AD, Bonatto SL and Salzano FM (2004) B-F DNA sequence variability in Brazilian (blue-egg Caipira) chickens. Anim Genet 35:278-284.

Marle-Köster E and Nel LH (2000) Genetic characterization of native southern African chicken populations: Evaluation and selection of polymorphic microsatellite markers. South Afr J Anim Sci 30:1-6.

McConnell SKJ, Dawson DA, Wardle A and Burke T (1999) The isolation and mapping of 19 tetranucleotide microsatellite markers in the chicken. Anim Genet 30:183-189.

Ramos MA (1995) O caipira de sangue azul. Globo Rural 113:39-43.

Roff DA and Bentzen P (1989) The statistical analysis of mitochondrial DNA polymorphisms: $\chi^{2}$ and the problem of small samples. Mol Biol Evol 6:539-545.

Sambrook J, Fritsch EF and Maniatis T (1989) Molecular Cloning - A Laboratory Manual, 2nd edition. Cold Spring Harbor Laboratory Press, Cold Spring Harbor, 236 pp.

Schneider S, Kueffer J-M, Roessli D and Excoffier L (2000) Arlequin ver. 2000: A software for population data analysis.
Genetics and Biometry Laboratory, University of Geneva, Geneva.

Takahashi H, Nirasawa K, Nagamine Y, Tsudzuki M and Yamamoto Y (1998) Genetic relationships among Japanese native breeds of chicken based on microsatellite DNA polymorphisms. J Hered 89:543-546.

Wain HM, Toye AA, Hughes S and Bumstead N (1998) Targeting of marker loci to chicken chromosome 16 by representational difference analysis. Anim Genet 29:446-452.

Wardecka B, Olszewski R, Jaszczak K, Zieba G, Pierzchala M and Wicinska K (2002) Relationship between microsatellite marker alleles on chromosomes 1-5 originating from the Rhode Island Red and Green-legged Partrigenous breeds and egg production and quality traits in $\mathrm{F} 2$ mapping population. J Appl Genet 43:319-329.

Wimmers K, Ponsuksili S, Schmoll F, Hardge T, Sonaiya EB, Schellander K and Horst P (1999) Application of microsatellite analysis to group chicken according to their genetic similarity. Arch Tierz 42:629-639.

Wimmers K, Ponsuksili S, Hardge T, Valle-Zarate A, Mathur PK and Horst P (2000) Genetic distinctness of African, Asian and South American local chickens. Anim Genet 31:159-165.

Yunis R, Heller ED, Hillel J and Cahaner A (2002) Microsatellite markers associated with quantitative trait loci controlling antibody response to Escherichia coli and Salmonella enteritidis in young broilers. Anim Genet 33:407-414.

Zhou H and Lamont SJ (1999) Genetic characterization of biodiversity in highly inbred chicken lines by microsatellite markers. Anim Genet 30:256-264.

Associate Editor: Pedro Franklin Barbosa 